\title{
PENGARUH ASIMETRI INFORMASI DAN UKURAN PERUSAHAAN TERHADAP MANAJEMEN LABA PADA PERUSAHAAN FOOD DAN BEVERAGES YANG $G O$ PUBLIC DI BURSA EFEK INDONESIA
}

\author{
Erisa Malau \\ Potak Parhusip
}

\begin{abstract}
Abstrak
Penelitian ini bertujuan untuk mengetahui apakah simetri informasi dan ukuran perusahaan berpengaruh secara parsial maupun secara simultan terhadap manajemen laba pada perusahaan food and beverages yang go public di Bursa Efek Indonesia tahun 20112013. Data yang digunakan dalam penelitian ini adalah data sekunder dan pemilihan sampel dengan menggunakan metode purposive sampling. Berdasarkan hasil purposive sampling dari 17 perusahaan diperoleh 14 perusahaan food and beverages yang memenuhi kriteria sampel. Metode analisis yang digunakan adalah metode analisis linier berganda untuk menguji pengaruh asimetri informasi dan ukuran perusahaan terhadap manajemen laba. Hasil penelitian menunjukkan bahwa asimetri informasi dan ukuran perusahaan secara simultan tidak berpengaruh signifikan terhadap manajemen laba pada perusahaan food and beverages yang go public di Bursa Efek Indonesia. Asimetri informasi secara parsial berpengaruh positif tetapi tidak signifikan terhadap Manajemen Laba pada perusahaan food and beverages yang go public di Bursa Efek Indonesia. Ukuran perusahaan secara parsial berpengaruh positif dan signifikan terhadap Manajemen Laba pada perusahaan food and beverages yang go public di Bursa Efek Indonesia.
\end{abstract}

Kata kunci: Asimetri Informasi, Ukuran Perusahaan dan Manajemen Laba.

\section{PENDAHULUAN}

Laporan keuangan merupakan sarana pengkomunikasian informasi keuangan kepada pihak-pihak di luar korporasi. Informasi laba sebagai bagian dari laporan keuangan, sering menjadi target rekayasa melalui tindakan oportunitis manajemen untuk memaksimumkan kepuasannya dan dapat merugikan pemegang saham atau investor. Dalam penyusunan laporan keuangan, dasar akrual dipilih karena secara umum memberikan indikasi lebih baik tentang kinerja ekonomi perusahaan daripada informasi yang dihasilkan dari penerimaan dan pengeluaran kas terkini. Namun, disisi lain penggunaan dasar akrual dapat memberikan keleluasaan kepada pihak manajemen dalam memilih metode akuntansi selama tidak menyimpang dari Standar Akuntansi Keuangan yang berlaku. Pilihan metode akuntansi yang sengaja dipilih oleh manajemen laba atau earnings management (Rahmawati, dkk).

Dalam teori keagenan (agency theory), hubungan agensi muncul karena adanya suatu kontrak yang dilakukan oleh satu orang atau lebih 
principal yang mempekerjakan orang lain (agent) untuk memberikan suatu jasa dan mendelegasikan wewenang pengambilan keputusan kepada agen. Manajer sebagai pihak pengelola perusahaan lebih banyak mengetahui informasi internal dan prospek perusahaan di masa yang akan datang dibandingkan pemilik. Oleh karena itu, manajer berkewajiban mamberikan sinyal mengenai kondisi perusahaan yang sesungguhnya kepada pemilik. Akan tetapi, informasi yang disampaikan terkadang tidak sesuai dengan kondisi perusahaan yang sesungguhnya. Ketidakseimbangan penguasaan informasi akan memicu munculnya suatu kondisi yang disebut sebagai asimetri informasi (information asymmetry).

Asimetri informasi merupakan suatu keadaan dimana manajer memiliki akses informasi yang lebih banyak mengenai prospek perusahaan yang tidak dimiliki oleh pihak eksternal perusahaan. Keberadaan asimetri informasi dianggap sebagai penyebab manajemen laba. Hubungan sistematis antara asimetri informasi dengan tingkat manajemen laba adalah adanya asimetri informasi akan mendorong manajer untuk menyajikan informasi yang tidak sebenarnya terutama jika informasi tersebut berkaitan dengan pengukuran kinerja manajer. Selain asimetri informasi, faktor yang lain yang mempengaruhi praktik manajemen laba yaitu ukuran perusahaan. Ukuran perusahaan merupakan nilai yang menunjukkan besar kecilnya perusahaan. Terdapat dua pandangan tentang bentuk hubungan ukuran perusahaan dan manajemen laba. Pandangan pertama menyatakan bahwa ukuran perusahaan memiliki hubungan positif dengan manajemen laba, karena perusahaan besar memiliki aktivitas operasional yang lebih kompleks dibandingkan perusahaan kecil, sehingga lebih memungkinkan untuk melakukan manajemen laba. Pandangan kedua menyatakan ukuran perusahaan memiliki hubungan negatif dengan manajemen laba. Perusahaan yang berukuran besar memiliki kecendrungan melakukan tindakan manajemen laba yang lebih kecil dibanding dengan perusahaan berukuran kecil. Hal ini dikarenakan perusahaan besar dipandang lebih kritis oleh pemegang saham dan pihak luar sehingga perusahaan besar mendapat tekanan yang lebih kuat untuk menyajikan laporan keuangan yang credible (Marihot dan Setyawan,2007).

Berdasarkan identifikasi masalah yang telah diuraikan di atas, maka tujuan penelitian ini adalah untuk mengetahui apakah simetri informasi dan ukuran perusahaan berpengaruh secara parsial maupun secara simultan terhadap manajemen laba pada perusahaan food and beverages yang go public di Bursa Efek Indonesia tahun 2011-2013. 


\section{TINJAUAN PUSTAKA DAN PENGEMBANGAN HIPOTESIS}

\section{Manajamen Laba}

Scott (2009) mendefinisikan manajemen laba adalah suatu tindakan manajer yang dilakukan melalui pilihan kebijakan akuntansi untuk memperoleh tujuan tertentu. Sedangkan menurut Kieso (2011) mendefinisikan manajemen laba sebagai perencanaan waktu dari pendapatan, beban, keuntungan, dan kerugian untuk meratakan fluktuasi laba.

Definisi lain menurut Schipper dalam Gumanti (2000) yaitu manajemen laba sebagai upaya yang dilakukan manajer untuk memperoleh keuntungan-keuntungan pribadi tertentu. Dari definisi tersebut jelas bahwa manajemen laba merupakan intervensi langsung manajemen dalam proses pelaporan keuangan dengan maksud untuk mendapatkan keuntungan atau manfaat tertentu. Menurut Badruzaman (2010) "Manajemen laba adalah cara yang ditempuh manajemen dalam mengelola perusahaan melalui pemilihan kebijakan akuntansi tertentu dengan tujuan untuk meningkatkan laba bersih dan nilai perusahaan sesuai dengan harapan manajemen".

Menurut Nuryaman (2008) "Manajemen Laba adalah suatu kondisi di mana manajemen melakukan intervensi dalam proses penyusunan laporan keuangan bagi pihak eksternal sehingga dapat meratakan, menaikan, dan menurunkan pelaporan laba". Sri (2008) mendefinisikan manajemen laba sebagai "Upaya manajer perusahaan untuk mengintervensi atau mempengaruhi informasi-informasi dalam laporan keuangan dengan tujuan untuk mengelabui stakeholder yang ingin mengetahui kinerja dan kondisi perusahaan".

Berdasarkan beberapa definisi di atas, maka dapat disimpulkan bahwa manajemen laba merupakan suatu tindakan yang dilakukan oleh manajer dengan cara memanipulasi data atau informasi akuntansi agar jumlah laba yang tercatat dalam laporan keuangan sesuai dengan keinginan manajer, baik untuk kepentingan pribadi maupun kepentingan perusahaan.

Perilaku manajemen laba dapat dijelaskan di dalam Positive Accounting Theory (PAT) dan teori keagenan (agency theory). Menurut Scott (2009) mendefinisikan Positive Accounting Theory (PAT) adalah memprediksi tindakan seperti pilihan kebijakan akuntansi oleh manajer perusahaan dan bagaimana manajer akan menanggapi usulan standar akuntansi baru. Terdapat tiga hipotesis dalam teori Positive Accounting Theory (PAT) yang dapat dijadikan sebagai dasar pemahaman motivasi tindakan manajemen laba menurut Watts dan Zimmerman (Scott, 2009) yaitu: 


\section{a. The Bonus Plan Hypothesis}

Hipotesis ini menyatakan bahwa manajer perusahaan dengan rencana bonus lebih mungkin untuk memilih prosedur akuntansi yang menggeser laba yang dilaporkan dari periode mendatang ke periode berjalan.

\section{b. The Debt Covenant Hypothesis}

Hipotesis ini menyatakan bahwa semua hal yang lain tetap sama dan semakin dekat perusahaan dengan pelanggaran perjanjian hutang dan semakin besar probabilitas pelanggaran perjanjian hutang tersebut, maka semakin mungkin manajer menggunakan metode akuntansi yang akan meningkatkan laba yang dilaporkan pada periode mendatang ke periode sekarang.

\section{c. The Political Cost Hypothesis}

Hipotesis ini menyatakan jika pada perusahaan yang besar memiliki biaya politik tinggi, maka manajer akan lebih memilih metode akuntansi yang dapat menurunkan laba yang dilaporkan dari periode sekarang ke periode mendatang. Hal ini dilakukan dengan tujuan untuk menghindari regulasi atau keputusan pemerintah, misalnya menaikkan pajak penghasilan perusahaan.

Teknik manajemen laba menurut Setiawati dan Na'im (2000) dapat dilakukan dengan tiga teknik, yaitu:

a. Memanfaatkan peluang untuk membuat estimasi akuntansi

Cara manajemen mempengaruhi laba melalui perkiraan (judgement) terhadap estimasi akuntansi antara lain estimasi tingkat piutang tak tertagih, estimasi kurun waktu depresiasi aktiva tetap atau amortisasi aktiva tak berwujud, estimasi biaya garansi, dan lain-lain.

b. Mengubah metode akuntansi

Perubahan metode akuntansi yang digunakan untuk mencatat suatu transaksi, contoh: mengubah metode depresiasi aktiva tetap dari metode depresiasi angka tahun ke metode depresiasi garis lurus.

c. Menggeser periode biaya atau pendapatan

Contoh rekayasa periode biaya atau pendapat antara lain: mempercepat/menunda pengeluaran untuk penelitian dan pengembangan sampai pada periode berikutnya, mempercepat/menunda pengeluaran promosi sampai periode berikutnya, mempercepat/menunda pengiriman produk ke pelanggan, mengatur saat penjualan aktiva tetap yang sudah tidak dipakai. 
Penelitian yang berkaitan dengan deteksi perilaku earnings management selain bertujuan untuk memahami dorongan yang mendasari perilaku tersebut, juga untuk memahami teknik yang dapat digunakan dalam mendeteksi perilaku tersebut. Pada kenyataannya, perusahaan yang terdaftar di pasar modal tidak seluruhnya terbebas dari earnings management, meskipun perusahaan tersebut telah diaudit oleh auditor independen. Apalagi dengan kebebasan yang diberikan Standar Akuntansi Keuangan, maka perusahaan dapat beralih menggunakan suatu fasilitas atas manipulasi yang digunakan.

Penelitian yang berkaitan dengan metode deteksi earnings management antara lain dilakukan oleh Dechow, et al yang mengevaluasi berbagai alternatif model untuk deteksi earnings management berdasarkan accruals. Perbandingan dilakukan terhadap lima model, yaitu model Healy, model De Angelo, model Jones, model Modified Jones, dan model Industri. Pengujian dilakukan untuk mengetahui kemampuan model dengan menerapkan pengujian statistik.

Pendekatan total accruals yang digunakan dalam penelitian ini sejalan dengan model awal yang dikembangkan oleh Healy dan De Angelo, dan Friedlan (dalam Hendra, Yie, 2005). Healy dan De Angelo berpendapat bahwa total accruals terdiri atas discretionary accruals dan nondiscretionary accruals, dimana total accruals tidak mudah terobservasi. Pendekatan ini berasumsi bahwa komponen non-discretionary accruals cenderung stabil sepanjang waktu, sehingga yang layak untuk dipertimbangkan adalah komponen discretionary accruals. Karena salah satu alasan utama perusahaan go public adalah pesatnya pertumbuhan, maka perlu dilakukan penyesuaian terhadap pengukuran discretionary accruals. Penyesuaian dilakukan untuk mengurangi kemungkinan bahwa pengukuran discretionary accruals sepenuhnya dipengaruhi oleh pertumbuhan.

Menurut Chan, Jegadesh, dan Lakonoshok (2001), discretionary accrual merupakan laba abnormal yang sebagian besar dikarenakan oleh item non-kas yang mewakili manipulasi laba. Discretionary accruals digunakan sebagai indikator adanya praktik manajemen laba, karena manajemen laba lebih menekankan pada keleluasaan atau kebijakan (discretion) yang tersedia dalam memilih dan menerapkan prinsip-prinsip akuntansi untuk mencapai hasil akhir, dan dijalankan dalam kerangka praktik yang berlaku secara umum yang masih diperdebatkan. Atau dengan kata lain, discretionary accruals merupakan accruals dimana manajemen memiliki fleksibilitas dalam mengontrol jumlahnya karena discretionary accruals ada di bawah kebijaksanaan manajemen. 


\section{Asimetri Informasi}

Menurut Komalasari (2001) menyatakan bahwa asimetri informasi adalah istilah untuk menggambarkan adanya dua kondisi investor dalam perdagangan saham yaitu investor yang more informed dan investor yang less informed.

Informasi yang lebih banyak dimiliki oleh manajer dapat memicu untuk melakukan tindakan-tindakan sesuai dengan keinginan dan kepentingan untuk memaksimumkan utilitynya. Sedangkan bagi pemilik modal dalam hal ini investor, akan sulit untuk mengontrol secara efektif tindakan yang dilakukan oleh manajemen karena hanya memiliki sedikit informasi yang ada. Oleh karena itu, terkadang kebijakan-kebijakan tertentu yang dilakukan oleh manajemen perusahaan tanpa sepengetahuan pihak pemilik modal atau investor.

Asimetri informasi timbul ketika manajer lebih mengetahui informasi internal dan prospek perusahaan di masa depan dibandingkan pemegang saham/ stakeholders lainnya. Dengan demikian beberapa konsekuensi tertentu hanya akan diketahui pihak lain yang juga memerlukan informasi tersebut (Silivia dan Yanivi, 2003). Oleh karena itu sebagai pengelola manajer berkewajiban memberikan sinyal mengenai kondisi perusahaan kepada pemilik. Sinyal yang diberikan dapat dilakukan melalui pengungkapan informasi akuntansi seperti laporan keuangan.

Menurut Ujiyanto dan Bambang (2007), menyatakan bahwa agent berada pada posisi yang memiliki lebih banyak informasi mengenai kapasitas diri, lingkungan kerja dan perusahaan secara keseluruhan dibandingkan dengan principal. Dengan asumsi bahwa individu-individu betindak untuk memaksimalkan untuk kepentingan diri sendiri, maka dengan informasi asimetri yang dimilikinya akan mendorong agent untuk menyembunyikan beberapa informasi yang tidak diketahui principal. Sehingga dalam kondisi semacam ini principal seringkali pada posisi yang tidak diuntungkan.

Laporan keuangan dimaksudkan untuk digunakan oleh berbagai pihak, termasuk manajemen perusahaan itu sendiri. Namun yang paling berkepentingan dengan laporan keuangan sebenarnya adalah para pengguna eksternal (di luar manajemen). Laporan keuangan tersebut penting bagi para pengguan eksternal terutama karena kelompok ini berada dalam kondisi yang paling besar ketidakpastiaannya (Ali, 2002). Para pengguna internal (para manajer) memiliki kontak langsung dengan entitas atau perusahaannya dan mengetahui peristiwa peristiwa signifikan terjadi, sehingga tingkat ketergantungan terhadap informasi akuntansi tidak 
sebesar para pengguna eksternal. Situasi ini akan memicu munculnya suatu kondisi yang disebut dengan asimetri informasi (information asymetry) yaitu suatu kondisi dimana ada ketidakseimbangan perolehan informasi antara pihak manajemen sebagai penyedian informasi (prepare) dengan pihak pemegang saham dan stakeholders pada umumnya sebagai pengguna informasi (user).

Menurut Scott (2009), terdapat 2 (dua) macam asimetri informasi yaitu:

a. Adverse selection

Adverse selection adalah jenis informasi yang diperoleh antara satu pihak dan lainnya berada ketika akan atau melangsungkan suatu transaksi bisnis. Adverse selection ini timbul karena manajer perusahaan dan orang dalam (insider) lain yang mengetahui lebih banyak mengenai kondisi terkini dan prospek mendatang dari suatu perusahaan dari para investor sebagai pihak luar.

\section{b. Moral Hazard}

Moral hazard adalah jenis informasi dimana satu pihak dapat mengamati tindakan pihak lain sedangkan pihak lainnya tidak dapat mengamati. Moral hazard timbul karena adanya pemisahan kepemilikan dan pengendalian yang merupakan karakter sebagian besar entitas bisnis besar.

Dalam melakukan pengukuran terhadap asimetri informasi, penulis menggunakan proksi bid-ask spread. Bid-ask speread adalah selisih dari harga bid dan ask sehingga disebut bid-ask spread.

a. Berdasarkan analyst forecast.

Metode ini dikembangkan berdasarkan pemikiran dari Blackwell dan Dubins. Proxy yang digunakan adalah keakuratan analis dalam melakukan prediksi atas earning per share (EPS) dan diprediksi para analis sebagai ukuran asimetri informasi.

Masalah yang sering timbul dari perhitungan ini adalah para analis seringkali bersikap over-reacting terhadap informasi positif dan bersikap under-reacting terhadap informasi negatif. Selain itu, penggunaan forecast error sebagai cara menghitung asimetri informasi selalu tidak berhubungan dengan tingkat risiko yang dihadapi oleh perusahaan melainkan mungkin berhubungan dengan fluktuasi dari earning dan bukan disebabkan oleh asimetri informasi yang lebih tinggi. Namun, Chung, et al dalam Wasilah (2005), berpendapat bahwa ada hubungan yang positif antara pendapat dengan selisih harga bid-ask. 
b. Berdasarkan kesempatan berinvestasi.

Bahwa perusahaan dengan tingkat pertumbuhan tinggi mempunyai kemampuan lebih baik untuk memprediksi arus kas pada periode mendatang, prediksi tersebut berdasarkan aset perusahaan. Beberapa proksi yang banyak digunakan adalah rasio market value to book value dari ekuitas, market to book value dari asset, price earning ratio. Alasan penggunaan rasio tersebut adalah:

- Rasio market to book value dari ekuitas dan asset, selain mencerminkan kinerja perusahaan, juga mencerminkan potensi pertumbuhan perusahaan dengan aset yang dimilikinya.

- Price earning ratio mencerminkan risiko dari pertumbuhan earning yang dihadapi perusahaan.

c. Berdasarkan teori market microstructure.

Yang menjadi perhatian luas dari teori ini adalah bagaimana harga dan volume perdagangan dapat terbentuk. Untuk melihat kedua faktor tersebut terbentuk melalui bid-ask spread yang menyatakan bahwa terdapat suatu komponen spread yang turut memberikan kontribusi kerugian yang dialami dealer (perusahaan) ketika melakukan transaksi dengan pedagang terinformasi (informed traders). Bid-ask spread merupakan selisih harga beli tertinggi dimana trader (pedagang saham) bersedia membeli suatu saham dengan harga jual terendah dimana trader bersedia menjual saham tersebut.

\section{Teori Bid-Ask Spread}

Jika seorang investor ingin membeli atau menjual suatu saham atau sekuritas lain di pasar modal, dia biasanya melakukan transaksi melalui broker/dealer yang memiliki spesialisasi dalam suatu sekuritas. Broker/dealer inilah yang siap untuk menjual pada investor untuk harga ask jika investor ingin membeli suatu sekuritas. Jika investor sudah mempunyai suatu sekuritas dan ingin menjualnya, maka broker/dealer ini yang akan membeli sekuritas dengan harga bid. Perbedaan antara harga bid dan harga ask adalah spread. Jadi, bid-ask spread merupakan selisih harga beli tertinggi bagi broker/dealer bersedia untuk membeli suatu saham dan harga jual dimana broker/dealer bersedia untuk menjual saham tersebut.

Dalam mekanisme pasar modal, pelaku pasar juga menghadapi masalah keagenan. Partisipan pasar saling berinteraksi di pasar modal guna mewujudkan tujuannya, membeli atau menjual sekuritas. Aktivitas yang mereka lakukan utamanya dipengaruhi oleh informasi yang diterima, baik secara langsung laporan publik) maupun tidak langsung (insider trading). 
Dealers atau market makers sebagai salah satu partisipan pasar modal mempunyai kemampuan yang terbatas terhadap persepsi yang akan datang, dan menghadapi potensi kerugian dari pedagang yang terinformasi (informed traders) karena mereka tidak memiliki informasi yang superior sebagaimana pedagang yang terinformasi. Timbulnya masalah adverse selection yang mendorong dealer untuk menutupi kerugian dari pedagang yang terinformasi dengan meningkatkan spread-nya terhadap pedagang yang liquid. Jadi, dapat dikatakan bahwa asimetri informasi yang terjadi antara dealer dan pedagang yang terinformasi tercermin pada spread yang ditentukannya (Komalasari, 2001).

\section{Ukuran Perusahaan}

Ukuran perusahaan menunjukkan besarnya skala perusahaan. Ukuran perusahaan dapat diukur oleh total aktiva (asset). Aktiva itu sendiri menurut Kieso (2011) adalah sebagai berikut: aktiva adalah sumber daya dikendalikan oleh suatu perusahaan sebagai akibat peristiwa masa lalu dan diharapkan akan mendapat manfaat ekonomi masa depan untuk perusahaan.

Ukuran perusahaan merupakan salah satu faktor yang berpengaruh terhadap manajemen laba perusahaan. Perusahaan besar cenderung bertindak hati-hati dalam melakukan pengelolaan perusahaan dan cenderung melakukan pengelolaan laba secara efisien. Perusahaan yang besar lebih diperhatikan oleh masyarakat sehingga mereka akan lebih berhati-hati dalam melakukan pelaporan keuangan, sehingga berdampak perusahaan tersebut melaporkan kondisinya lebih akurat (Nasution dan Setiawan, 2007). Veronica dan Utama (2005) menemukan bukti adanya pengaruh negatif antara ukuran perusahaan terhadap manajemen laba. Hasil serupa juga dikemukakan oleh Nuryaman (2008) bahwa ukuran perusahaan berpengaruh negatif terhadap manajemen laba. Oleh karena itu, dapat disimpulkan bahwa ukuran perusahaan yang besar dapat mengurangi praktik manajemen laba perusahaan.

Perusahaan yang berukuran besar memiliki basis pemegang kepentingan yang lebih luas, sehingga berbagai kebijakan perusahaan besar akan berdampak lebih besar terhadap kepentingan publik dibandingkan dengan perusahaan kecil. Bagi investor, kebijakan perusahaan akan berimplikasi terhadap prospek cash flow dimasa yang akan datang. Sedangkan bagi regulator (pemerintah) akan berdampak terhadap besarnya pajak yang akan diterima, serta efektivitas peran pemberian perlindungan terhadap masyarakat secara umum. 
Ukuran perusahaan yang biasa dipakai untuk menentukan tingkat perusahaan adalah:

1. Tenaga kerja, merupakan jumlah pegawai tetap dan kontraktor yang terdaftar atau bekerja di perusahaan pada suatu saat tertentu.

2. Tingkat penjualan, merupakan volume penjualan suatu perusahaan pada suatu periode tertentu misalnya satu tahun.

3. Total utang ditambah dengan nilai pasar saham biasa, merupakan jumlah utang dan nilai pasar saham biasa perusahaan pada saat atau suatu tanggal tertentu.

4. Total aset, merupakan keseluruhan aktiva yang dimiliki perusahaan pada saat tertentu.

\section{Kerangka Berpikir}

Penelitian ini menggunakan 2 (dua) variabel independen yang diduga berpengaruh terhadap manajemen laba pada perusahaan manufaktur sektor industri food and beverages yang go public di Bursa Efek Indonesia. Maka pengaruh masing-masing variabel independen terhadap manajemen laba dapat dijelaskan sebagai berikut :

\section{a. Pengaruh Asimetri Informasi terhadap Manajamen Laba}

Asimetri informasi timbul ketika manajer lebih mengetahui informasi internal dan prospek perusahaan di masa depan dibandingkan dengan pemegang saham dan stakeholder lainnya. Informasi yang lebih banyak dimiliki manajer dapat memicu untuk melakukan tindakan-tindakan sesuai dengan keinginan manajer dan kepentingan untuk memaksimumkan utility-nya. Adanya asimetri informasi akan mendorong manajer untuk menyajikan informasi yang tidak sebenarnya, terutama jika informasi tersebut berkaitan dengan pengukuran kinerja manajer. Oleh karena itu sebagai pengelola, manajer berkewajiban memberikan report mengenai kondisi perusahaan kepada pemilik. Report yang diberikan dapat dilakukan melalui pengungkapan informasi akuntansi seperti laporan keuangan.

Laporan keuangan tersebut penting bagi para pengguna eksternal terutama sekali karena kelompok ini berada dalam kondisi yang paling besar ketidakpastiannya (Ali, 2002). Para pengguna internal (para manajemen) memiliki kontak langsung dengan entitas atau perusahaannya dan mengetahui peristiwa- peristiwa signifikan yang terjadi, sehingga tingkat ketergantungan terhadap informasi akuntansi tidak sebesar para pengguna eksternal.

Dalam penyusunan laporan keuangan, dasar akrual dipilih karena lebih rasional dan adil dalam mencerminkan kondisi keuangan perusahaan 
secara riil namun disisi lain penggunaan dasar akrual dapat memberikan keleluasan kepada pihak manajemen dalam memilih metode akuntansi selama tidak menyimpang dari Standar Akuntansi Keuangan yang berlaku. Pilihan metode akuntansi yang secara sengaja dipilih oleh manajemen untuk tujuan tertentu dikenal dengan sebutan manajemen laba.

Banyak hal yang memotivasi manajer untuk melakukan manajemen laba. Menurut Scott (2009), motivasi manajemen laba meliputi rencana bonus, debt covenant, dan biaya politik. Manajer termotivasi mengelola laba untuk mencapai target kinerja dan kompensasi bonus, meminimalkan kemungkinan pelanggaran perjanjian utang, dan meminimalkan biaya politik karena intervensi pemerintah dan parlemen, namun fleksibilitas manajemen untuk mengelola laba dapat dikurangi dengan menyediakan informasi yang lebih berkualitas bagi pihak luar. Kualitas laporan keuangan akan mencerminkan tingkat manajemen laba dari perusahaan itu sendiri.

Beberapa peneliti telah menemukan bahwa asimetri informasi dapat mempengaruhi manajemen laba. Teori Keagenan (Agency Theory) mengimplikasikan adanya asimetri informasi antara manajer untuk melakukan manajemen laba yang bertujuan untuk bertindak opportunistic yaitu memaksimalkan keuntungan pribadi.

Richardson (2000) melakukan pangujian asimetri informasi yang mempengaruhi manajer untuk melakukan earning management: Ketika asimetri informasi tinggi, stakeholder tidak memiliki sumber daya yang cukup atas informasi yang relevan dalam memonitor tindakan manajer sehingga akan memunculkan praktik manajemen laba. Akibatnya asimetri informasi ini akan mendorong manajer untuktidak menyajikan informasi selengkapnya. Jika informasi tersebut berkaitan dengan pengukuran kinerja manajer.

Penelitian yang dilakukan oleh Wasilah (2005) juga menunjukkan bahwa variabel independen asimetri informasi berpengaruh secara positif signifikan dan mampu menjelaskan variabel dependen manajemen laba. Berdasarkan analisis diatas, peneliti menduga bahwa asimetri informasi yang tinggi cenderung untuk melakukan manajemen laba.

\section{b. Pengaruh Ukuran Perusahaan Terhadap Manajemen Laba}

Ukuran perusahaan dapat didefinisikan sebagai upaya penilaian besar atau kecilnya sebuah perusahaan. Pada umumnya penelitian di Indonesia menggunakan total aktiva atau total penjualan sebagai proksi dari ukuran perusahaan. Perusahaan yang lebih besar kurang memiliki dorongan untuk melakukan manajemen laba dibandingkan perusahaan-perusahaan kecil 
karena perusahaan besar dipandang lebih kritis oleh pihak luar, baik oleh investor, kreditor, pemerintah maupun masyarakat. Ukuran perusahaan diduga mampu mempengaruhi besaran pengelolaan laba perusahaan, dimana jika pengelolaan laba tersebut oportunis maka semakin besar perusahaan semakin kecil pengelolaan laba (berhubungan negatif) tapi jika pengelolaan laba efisien maka semakin besar ukuran perusahaan semakin tinggi pengelolaan labanya (berhubungan positif) (Silvia dan Siddharta, 2005).

Terdapat dua pandangan yang berbeda mengenai bentuk hubungan ukuran perusahaan terhadap manajemen laba. Pandangan pertama menyatakan bahwa ukuran perusahaan memiliki hubungan positif dengan manajemen laba. Hal ini bisa dibuktikan pada penelitian Halim, dkk (2005) dengan data LQ-45 di Bursa Efek Indonesia (BEI) menemukan ukuran perusahaan berpengaruh positif terhadap manajemen laba.

Penelitian Nuryaman (2008) menemukan bahwa ukuran perusahaan memiliki hubungan negatif dengan manajemen laba. Ini mengindikasikan bahwa perusahaan besar kecenderungan melakukan tindakan manajemen labanya lebih kecil dibandingkan dengan perusahaan yang ukurannya lebih kecil. 
Gambar 1

Kerangka Berpikir

\begin{abstract}
Pengaruh Asimetri Informasi dan Ukuran Perusahaan terhadap Manajemen Laba pada Perusahaan Food and Beverages yang Go Public di Bursa Efek Indonesia
\end{abstract}

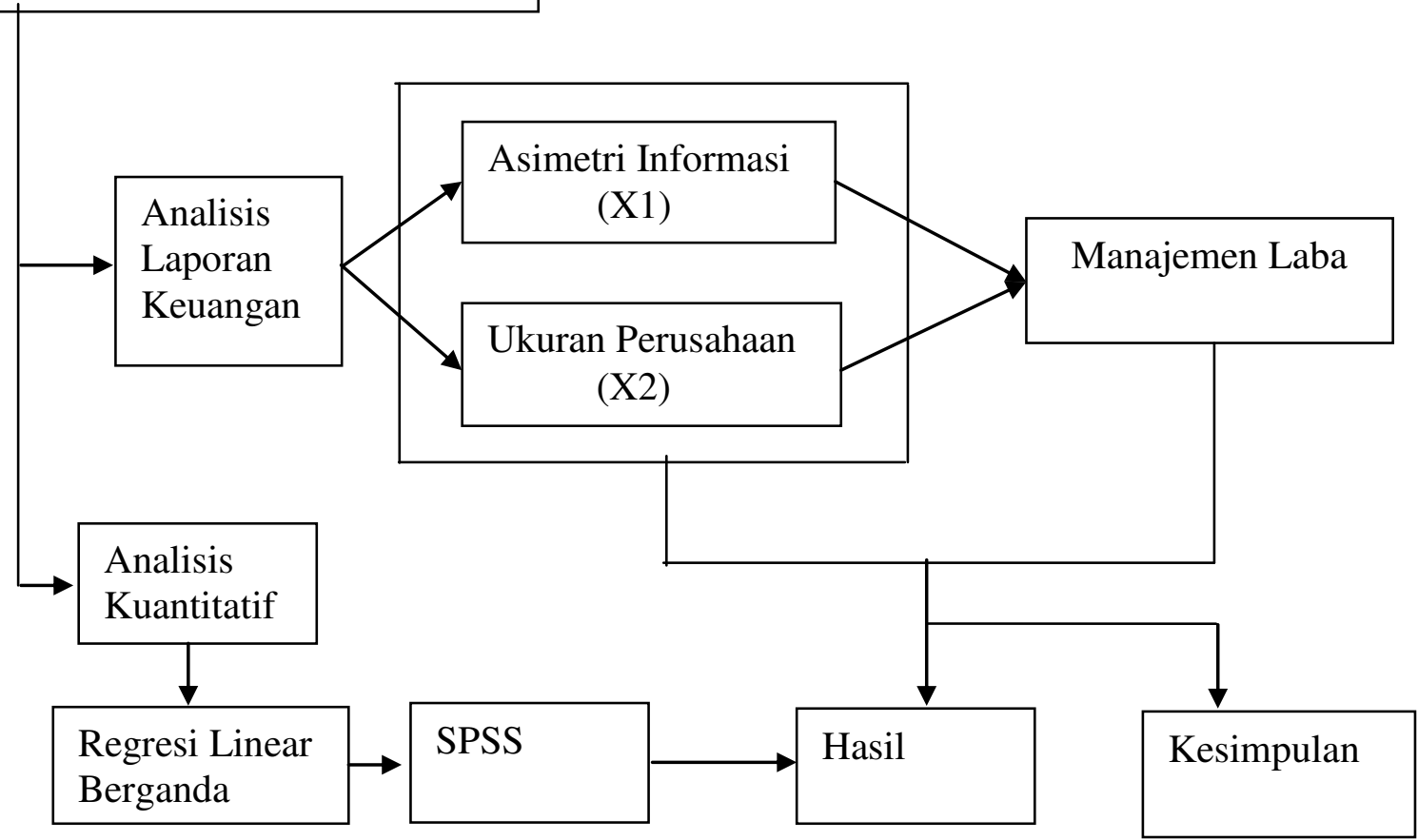

\title{
Hipotesis
}

Berdasarkan permasalahan diatas, maka hipotesis sementara dalam penelitian ini adalah :

$\mathrm{H}_{1}$ : Asimetri informasi berpengaruh terhadap manajemen laba

$\mathrm{H}_{2}$ : Ukuran (size) perusahaan berpengaruh terhadap manajemen laba

$\mathrm{H}_{3}$ : Asimetri informasi dan Ukuran perusahaan berpengaruh terhadap manajemen laba. 


\section{METODE PENELITIAN}

\section{Populasi dan Sampel}

Populasi penelitian ini adalah 17 perusahaan di sektor industri food and beverages yang tercatat di Bursa Efek Indonesia pada tahun 20112013. Tehnik pengambilan sampel menggunakan metode purposive sampling, yaitu pemilihan sampel atas dasar kesesuaian antara sampel dengan kriteria pemilihan tertentu.

Kriteria-kriteria pemilihan sampel tersebut terdiri dari:

1. Perusahaan food and beverages yang terdaftar di Bursa Efek Indonesia mulai tahun 2011 - 2013.

2. Perusahaan menerbitkan laporan keuangan untuk periode yang berakhir pada tanggal 31 Desember mulai tahun 2011 - 2013.

3. Perusahaan menerbitkan data transaksi bulanan perusahaan seperti harga ask (harga beli saham tertinggi), harga bid (harga jual terendah saham), yang dipublikasikan selama tahun pengamatan untuk periode yang berakhir pada tanggal 31 Desember 2011 sampai 31 Desember 2013.

4. Perusahaan yang menyajikan laporan keuangannya dalam mata uang Rupiah.

Berdasarkan kreteria tersebut maka jumlah sampel yang terpilih sebanyak 14 perusahaan dari 17 perusahaan yang merupakan 82,35\% dari seluruh perusahaan food and beverages yang terdaftar di Bursa Efek Indonesia selama tahun 2011 sampai dengan 2013

\section{Operasional Variabel}

\section{a. Asimetri informasi}

Asimetri informasi diukur dengan menggunakan Relative Bid-ask Spread, saham perusahaan atau selisih harga jual dan harga beli saham perusahaan selama satu tahun (Healy, 1999) dalam (Mayanda, 2008).

\section{SPREAD $=($ ask i,t - bid i,t $) /\{($ ask i,t+bid i,t $) / 2\} \times 100 \%$}

Variabel asimetri informasi menggunakan skala rasio dan satuan ukurannya persen $(\%)$

Keterangan:

Ask : harga tertinggi pada perusahaan i yang terjadi selama 1 tahun

Bid : harga terendah saham pada perusahaan i yang terjadi selama 1 tahun 


\section{b. Ukuran Perusahaan}

Ukuran perusahaan (UP) merupakan variabel yang diukur dari jumlah total asset perusahaan sampel. Jumlah total asset perusahaan ini kemudian dilakukan transformasi ke dalam bentuk logaritma natural (LN). Secara sistematis variabel size diformulasikan sebagai berikut (Chen, 2005)

\section{Ukuran Perusahaan $=$ Ln Total Asset}

Variabel ukuran perusahaan menggunakan skala pengukuran rasio dan satuan ukurannya adalah persen.

\section{c. Manajemen laba}

Manajemen laba (DACC) diukur dengan discretionary accruals yang dihitung dengan cara menselisihkan total accruals (TACC) dan nondiscretionary accruals (NDACC). Dalam menghitung DACC, digunakan model Friedlan (Hendra, Yie, 2005) dengan melakukan penyesuaian terhadap perhitungan total accruals yang memiliki asumsi bahwa proporsi yang konstan antara total accruals dan penjualan pada periode yang berurutan. Oleh karena itu, jumlah total accruals yang melekat pada diskresi manajemen merupakan perbedaan antara total accruals pada periode yang diuji dan standarisasi dengan penjualan pada periode yang diuji dan total accruals pada periode dasar yang distandarisasi dengan penjualan pada periode dasar. Secara formal perhitungannya adalah sebagai berikut:

1) Menghitung Total Accruals (TA) untuk periode $t$ dapat dinyatakan dengan persamaan sebagai berikut:

$$
\text { TACT }=\text { NIT }- \text { CFOT }
$$

Keterangan:

TACT : Total accruals pada periode $\mathrm{T}$.

NIT : Laba bersih operasi (operating income) periode $\mathrm{T}$.

CFOT : Aliran kas dari aktivitas operasi (cash flow from operating activities) pada akhir tahun $\mathrm{T}$

2) Mengukur Discretionary Accruals (DA) dengan menggunakan rumus:

$$
\text { DAC PT }=\frac{\text { TACpt }}{\text { salespt }}-\frac{\text { TACpd }}{\text { salespd }}
$$

Variabel manajemen laba menggunakan skala pengukuran rasio dan satuan ukurannya desimal. 
Keterangan:

DAC PT: discretionary accruals pada periode tes.

TAC PT: total accruals pada periode tes.

Sales PT: penjualan pada periode tes.

TAC PD: total accruals pada periode dasar.

Sales PD: penjualan pada periode dasar.

Indikasi bahwa telah terjadi earnings management ditunjukkan oleh koefisien DAC yang positif, sebaliknya bila koefisien DAC negatif berarti tidak ada indikasi bahwa manajemen telah melakukan upaya menaikkan keuntungan melalui income-increasing discretionary accruals.

\section{Teknik Analisis Data}

\section{a. Uji Asumsi Klasik}

Sebelum model regresi digunakan untuk menguji hipotesis, tentunya model tersebut harus bebas dari gejala asumsi klasik karena model yang baik harus memenuhi kriteria BLUE (Best Linear Unbiased Estimator). Adapun uji asumsi klasik yang digunakan adalah, Uji Normalitas, normalitas diuji dengan melihat grafik histogram (Ghozali, 2013). Uji Multikolinieritas, pengujian multikolinearitas dilakukan dengan melihat VIF (Variance Inflation Factor) antar variabel independen, (Ghozali, 2013)

Uji Autokorelasi, pengujian autokorelasi menggunakan uji Durbin Watson (DW test). Uji Heteroskedastisitas Uji heteroskedastisitas dilakukan dengan melihat grafik plot antara nilai prediksi variabel terikat(dependen) yaitu ZPRED dengan residualnya SRESID (Ghozali, 2013:139).

\section{b. Pengujian Hipotesis}

Tehnik analisis data yang digunakan dalam penelitian ini adalah regresi linier berganda yang bertujuan untuk menghitung besarnya hubungan dua atau lebih variabel independen dan memprediksi variabel dependen dengan menggunakan dua atau lebih variabel independen.

Model persamaanya adalah sebagai berikut:

\section{$\mathrm{Y}=\mathbf{a}+\mathbf{b} 1 \mathrm{X} 1+\mathbf{b} 2 \mathrm{X} 2+\mathrm{e}$}

Keterangan :

$\mathrm{Y}=$ Manajemen Laba

A $\quad=$ Konstanta

$\mathrm{b} 1, \mathrm{~b} 2=$ Koefisien regresi parsial untuk X1,X2

$\mathrm{X} 1=$ Asimetri Informasi

$\mathrm{X} 2=$ Ukuran perusahaan

e $=$ error 


\section{PEMBAHASAN}

\section{Hasil Uji Asumsi Klasik}

Pengujian asumsi klasik yang meliputi uji normalitas, uji multikolinieritas, uji autokorelasi dan uji heteroskedastisitas.

\section{a. Hasil Uji Normalitas}

Normalitas dapat dideteksi melalui pengamatan grafik histogram seperti yang disajikan pada gambar 2

Gambar 2

Grafik Histogram

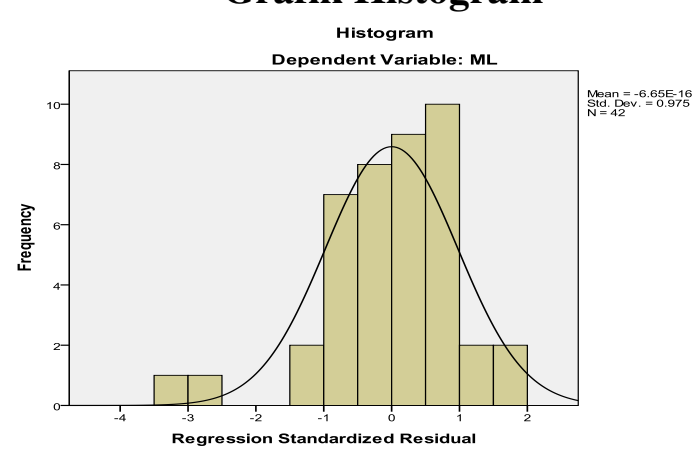

Sumber : Output SPSS

Dari gambar 2 terlihat bahwa grafik histogram memberikan pola distribusi normal. Dengan demikian sampel tersebut memenuhi syarat untuk di lakukan penelitian lebih lanjut.

\section{b. Hasi Uji Multikolinieritas}

Hasil uji multikolinieritas seperti pada tabel 1

\section{Tabel 1}

Hasil uji multikolinieritas

\begin{tabular}{|ll|c|c|}
\hline \multirow{2}{*}{} & \multirow{2}{*}{ Model } & \multicolumn{2}{|c|}{ Collinearity Statistics } \\
\cline { 2 - 4 } & Tolerance & VIF \\
\hline 1 & (Constant) & & \\
& AI & .895 & 1.117 \\
& UP & .895 & 1.117 \\
\hline
\end{tabular}

Sumber: Output SPSS

Dari tabel di atas, diketahui nilai VIF sebesar 1,117 dan 1,117. Dengan demikian, dapat dikatakan bahwa asimetri informasi dan ukuran perusahaan tidak mengalami multikolinieritas, karena nilai VIF lebih kecil dari 10. 


\section{c. Hasi Uji Autokorelasi}

Hasil uji autokorelasi seperti pada tabel berikut 2

\section{Tabel 2}

Hasil uji autokorelasi

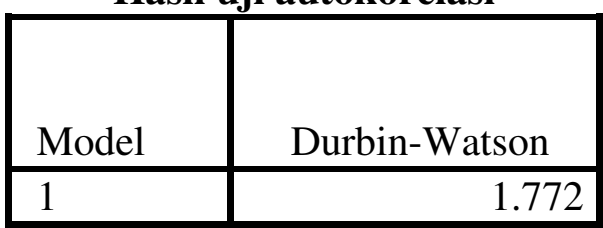

Sumber: Output SPSS

Dari tabel di atas, diketahui DW sebesar 1,772. Nilai ini akan dibandingkan dengan tabel DW dengan jumlah observasi $(n)=42$, jumlah variabel independen $(\mathrm{k})=2$ dan tingkat sigifikan 0,05 didapat nilai $\mathrm{dl}=$ 1,4073 dan nilai du=1,6061. Jadi dapat dihitung 4-du = 2,3939 dan 4-dl= 2,5927. Kriteria pengujian adalah $\mathrm{du}<\mathrm{d}<4$-du. Nilai du sebesar 1,6061, maka, 1,6061 < 1,772<2,3939. Artinya tidak ada autokorelasi positif atau negatif antara asimetri informasi dan ukuran perusahaan.

\section{d. Hasil Uji Heteroskedastisitas}

Berdasarkan hasil pengujian diperoleh hasil uji heteroskedastisitas, seperti pada gambar berikut.

\section{Gambar 2}

\section{Hasil uji heteroskedastisitas}

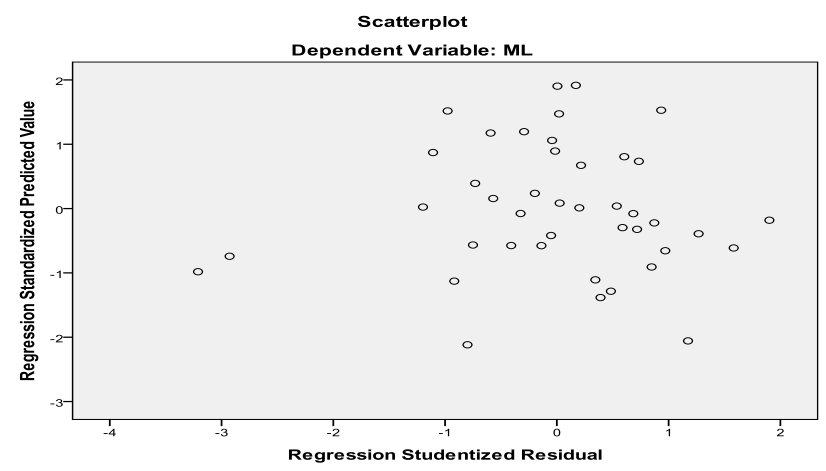

Sumber: Output SPSS

Dari gambar tersebut, diketahui bahwa titik-titik menyebar secara tidak teratur (pola tidak jelas) di atas dan di bawah angka 0 pada sumbu y. artinya tidak terjadi heteroskedastisitas. 


\section{Hasil Analisis Data}

Pengolahan data dan pengujian hipotesis dalam penelitian ini dilakukan dengan menggunakan alat bantu statistic yaitu program software komputer SPSS.

\section{a. Analisis Regresi Linier Berganda}

Hasil analisis regresi berganda dapat dilihat pada Tabel 3 berikut ini:

Tabel 3

Hasil Anaisis Regresi Linier Bergandan

\begin{tabular}{|c|c|c|c|c|c|c|}
\hline \multirow{2}{*}{\multicolumn{2}{|c|}{ Model }} & \multicolumn{2}{|c|}{$\begin{array}{l}\text { Unstandardized } \\
\text { Coefficients }\end{array}$} & \multirow{2}{*}{\begin{tabular}{|l|}
$\begin{array}{l}\text { Standardized } \\
\text { Coefficients }\end{array}$ \\
Beta \\
\end{tabular}} & \multirow[b]{2}{*}{$\mathrm{T}$} & \multirow[b]{2}{*}{ Sig. } \\
\hline & & $\mathrm{B}$ & Std. Error & & & \\
\hline \multirow[t]{3}{*}{1} & (Constant) & -.523 & .210 & & -2.485 & .017 \\
\hline & AI & .001 & .001 & .237 & 1.500 & .142 \\
\hline & UP & .029 & .013 & .361 & 2.291 & .027 \\
\hline
\end{tabular}

a Dependen Variabel: Manajemen Laba

Sumber: Output SPSS

Berdasarkan tabel di atas, diketahui nilai thitung 1,500 < ttabel 2,021 (diperoleh dari signifikan $0,05, \mathrm{n}=42, \mathrm{df}=\mathrm{n}-2=42-2=40$, dengan cara di Ms Excel ketik TINV $(0.05,40)=2,021$. Sehingga H1 ditolak dan H0 diterima, karena tingkat signifikan sebesar $0,142>0,05$. Artinya asimetri informasi secara parsial berpengaruh positif tetapi tidak signifikan terhadap manajemen laba pada perusahaan food and beverages yang go public di Bursa Efek Indonesia. Dengan demikian hipotesis ditolak.

Berdasarkan tabel 3 diketahui nilai thitung 2,291> ttabel 2,022, sehingga $\mathrm{H} 1$ diterima dan $\mathrm{H} 0$ ditolak, karena tingkat signifikan sebesar $0,027<0,05$. Artinya, ukuran perusahaan secara parsial berpengaruh positif dan signifikan terhadap Manajemen Laba pada perusahaan food and beverages yang go public di Bursa Efek Indonesia. Dengan demikian hipotesis diterima.

\section{b. Koefisien Determinasi $\left(\mathbf{R}^{2}\right)$}

Koefisien Determinasi $\left(\mathrm{R}^{2}\right)$ adalah angka yang menunjukkan besarnya derajat atau kemampuan distribusi variabel independen (X) dalam menjelaskan dan menerangkan variabel dependen (Y). Besar koefisien determinasi adalah antara nol dan satu $\left(0<\mathrm{R}^{2}<1\right)$. Berikut ini nilai koefisien determinasi $\left(\mathrm{R}^{2}\right)$ penelitian ini : 
Tabel 4

Koefisiensi Determinasi

\begin{tabular}{|c|c|c|c|c|c|}
\hline Model & $\mathrm{R}$ & R Square & $\begin{array}{l}\text { Adjusted } \\
\text { Square }\end{array}$ & $\mathrm{R}$ & $\begin{array}{l}\text { Std. Error of } \\
\text { the Estimate }\end{array}$ \\
\hline 1 & $.362^{\mathrm{a}}$ & .131 & .087 & & .1068536 \\
\hline
\end{tabular}

a. Predictor: (Constant), UP,AI

Sumber: Output SPSS

b. Dependent Variable: ML

Nilai koefisien determinan ( $R$ Square) sebesar 0,131. Artinya manajemen laba dapat dijelaskan oleh asimetri informasi dan ukuran perusahaan sebesar $13,1 \%$ sedangkan $86,9 \%$ dapat dijelaskan oleh faktor lain yang tidak dibahas pada penelitian ini.

\section{c. Pengujian Hipotesis Secara Simultan $(\mathbf{U j i}-\mathbf{F})$}

Uji - F digunakan untuk menguji apakah variabel independen secara bersama-sama mempengaruhi variabel dependen. Berikut ini hasil pengujian hipotesis secara simultan adalah sebagai berikut :

\section{Tabel 5}

Hasil Uji Hipotesis Secara Simultan

\begin{tabular}{|ll|l|l|l|l|l|}
\hline Model & & Sum of Squares & Df & Mean Square & F & Sig. \\
\hline 1 & Regression & .067 & 2 & .034 & 2.946 & $.064^{\mathrm{a}}$ \\
& Residual & .445 & 39 & .011 & & \\
& Total & .513 & 41 & & & \\
& & & & & & \\
\hline
\end{tabular}

a. Predictors: (Constant), UP, AI

b. Dependent Variable: ML

Sumber: Output SP

Berdasarkan tabel di atas, diketahui nilai Fhitung 2,946 < Ftabel 3,23 (diperoleh dari signifikan 0,05, df1=2, df2=n-k-1=42-2-1=39, dengan cara di Ms Excel ketik FINV(0.05,2,39) =3,23). Sehingga H1 ditolak dan H0 diterima, karena tingkat signifikan sebesar 0,064 > 0,05. Artinya, asimetri informasi dan ukuran perusahaan secara simultan tidak berpengaruh signifikan terhadap manajemen laba pada perusahaan food and beverages yang go public di Bursa Efek Indonesia. Dengan demikian hipotesis ditolak. 


\section{Pembahasan}

Hasil penelitian ini sesuai dengan penelitian Desmiyawati (2009) yang mengemukakan bahwa ukuran perusahaan secara parsial berpengaruh positif signifikan terhadap manajemen laba pada perusahaan manufaktur di Bursa Efek Indonesia. Tetapi, berbeda dengan hasil penelitian Mustika (2009) menyimpulkan bahwa ukuran perusahaan secara parsial berpengaruh negatif dan signifikan terhadap manajemen laba pada perusahaan food and beverages di Bursa Efek Indonesia.

Hasil penelitian ini juga didukung oleh landasan teori sebelumnya yang menyebutkan bahwa ukuran perusahaan berpengaruh terhadap manajemen laba. Ukuran perusahaan diduga mampu mempengaruhi besarnya pengelolaan laba perusahaan, dimana jika pengelolaan laba tersebut oportunis maka semakin besar perusahaan semakin kecil pengelolaan laba (berhubungan negatif) tapi jika pengelolaan laba efisien maka semakin besar ukuran perusahaan semakin tinggi pengelolaan labanya (berhubungan positif).

Jadi, dapat disimpulkan bahwa ukuran perusahaan berpengaruh positif dan signifikan terhadap manajemen laba. Artinya, bahwa perusahaan yang memiliki skala besar, maka cenderung melakukan manajemen laba.

Berdasarkan hasil uji t (parsial), diperoleh nilai thitung 1,500 < ttabel 2,021. Sehingga H1 ditolak dan H0 diterima, karena tingkat signifikan sebesar $0,142>0,05$. Artinya asimetri informasi secara parsial berpengaruh positif tetapi tidak signifikan terhadap Manajemen Laba pada perusahaan food and beverages yang go public di Bursa Efek Indonesia. Dengan demikian hipotesis ditolak.

Dilihat dari nilai koefisien regresinya diketahui bahwa pengaruh asimetri informasi terhadap manajemen laba sebesar 0,001. Artinya, jika asimetri informasi naik 1\% maka manajemen laba akan naik sebesar 0,001. Sebaliknya, jika asimetri informasi turun $1 \%$ maka manajemen laba akan turun sebesar 0,001. Dengan demikian terdapat pengaruh positif antara asimetri informasi terhadap manajemen laba.

Hasil penelitian ini tidak sesuai dengan hasil penelitian-penelitian sebelumnya yang menyimpulkan bahwa asimetri informasi secara parsial berpengaruh signifikan terhadap manajemen laba. Jadi dapat disimpulkan bahwa hasil penelitian ini juga bertolak belakang dengan landasan teori pada pembahasan sebelumnya. Perbedaan ini terjadi akibat perbedaan sampel dan data penelitian. 


\section{Kesimpulan}

Berdasarkan hasil pembahasan yang telah dilakukan pada bab sebelumnya, dapat disimpulkan bahwa:

1. Persamaan regresi linear berganda yang diperoleh adalah $\mathrm{Y}=$ $0,523+0,001 \mathrm{X} 1+0,029 \mathrm{X} 2$. Artinya asimetri informasi dan ukuran perusahaan berpengaruh positif terhadap manajemen laba pada perusahaan food and beverages yang go public di Bursa Efek Indonesia. Hal ini dapat dilihat dari nilai koefisien regresinya yang bertanda positif.

2. Hasil uji F, menunjukkan bahwa asimetri informasi dan ukuran perusahaan secara simultan tidak berpengaruh signifikan terhadap manajemen laba pada perusahaan food and beverages yang go public di Bursa Efek Indonesia. Dengan demikian hipotesis ditolak.

3. Hasil uji t, menunjukkan bahwa asimetri informasi secara parsial berpengaruh positif tetapi tidak signifikan terhadap Manajemen Laba pada perusahaan food and beverages yang go public di Bursa Efek Indonesia. Dengan demikian hipotesis ditolak. Dan ukuran perusahaan berpengaruh positif dan signifikan terhadap Manajemen Laba pada perusahaan food and beverages yang go public di Bursa Efek Indonesia. Dengan demikian hipotesis diterima.

\section{Saran}

Adapun saran yang berkaitan dengan penelitian ini adalah sebagai berikut:

1. Dilihat dari nilai koefisien determinan ( $R$ Square) sebesar 0,131. Artinya manajemen laba dapat dijelaskan oleh asimetri informasi dan ukuran perusahaan sebesar $13,1 \%$ sedangkan $86,9 \%$ dapat dijelaskan oleh factor lain yang tidak dibahas pada penelitian ini. Oleh sebab itu, sebaiknya peneliti lain menambah variabel leverage, konsentrasi kepemilikan, profitabilitas dan populasi penelitian agar hasil analisis lebih akurat.

2. Berdasarkan hasil penelitian diharapkan perusahaan-perusahaan yang bergerak dalam sektor industri food and beverages yang terdaftar di Bursa Efek Indonesia perlu memperhatikan faktor-faktor lain seperti leverage, konsentrasi kepemilikan, dan profitabilitas agar dapat meminimalisir kemungkinan adanya manajemen laba.

3. Penelitian ini hanya mengamati periode selama 3 tahun. Maka disarankan untuk penelitian selanjutnya mengamati periode penelitian 
yang lebih panjang agar diperoleh hasil yang berbeda dengan hasil penelitian ini.

\section{DAFTAR PUSTAKA}

Ali, Irfan. 2002. Pelaporan Keuangan dan Asimetri Informasi dalam Hubungan Agensi. Lintasan Ekonomi Vol. XIX No. 2.

Badruzaman, Nunung (2010). Earning management, Program Studi Akuntansi Fakultas Ekonomi. Bandung.

Chan, K., Chan L.K., Jegadesh, N., and Lakonishok, J. 2001. Earnings Qualityand Stock Returns. NBER Working Paper Series.

Fuad. 2005. Simultanitasdan "Trade-Off" Pengambilan Keputusan Finansial dalam Mengurangi KonflikAgensi: Perandari Corporate Ownership. Simposium Nasional Akuntansi VIII. Ikatan Akuntansi Indonesia.

Ghozali, Imam. 2005. Aplikasi Analisis Multivariate dengan Program SPSS. Semarang: Badan Penerbit Universitas Diponegoro.

Healy, Paul M. and J.M. Wahlen. 1998. A Review of The Earnings Management Literature and Its Implications for Standard Setting. Accounting Horizons, v. 13 (4), 1999, 365-83.

Kieso, D.E., J.J. Weigandt, dan T.D. Warfield. 2011. Intermediate Accounting IFRS Edition. Hoboken Willey.

Komalasari, Puput T. 2001. Asimetri Informasidan Cost of Equity Capital. Simposium Nasional Akuntansi III.

Meutia, Inten.2004. Pengaruh Independensi Auditor terhadap Manajemen laba untuk KAP Big 5 dan Non Big 5. Jurnal Riset Akuntansi Indonesia.Vol. 7, No. 3.

Nazir, Moh. 2003. Metode Penelitian. Cetakan Kelima. Jakarta: Ghalia Indonesia.

Sastradipraja, U. 2010. Analisis dan Penggunaan Laporan Keuangan pada Program Studi Akuntansi Fakultas Ekonomi. Bandung.

Schipper, K. (1989). "Commentary on Earnings Management". Accounting Horizon, 3: 91-102.

Scott, William R. 2009. Financial Accounting Theory. Fourth Edition. USA Prentice Hall, Inc.

Richardson, V. J. 1998. Information Asymmetry and Earnings Management: Some Evidence. http /www.ssrn.com.

Santoso, Purbayu Budi dan Ashari. 2005. Analisis Statistik dengan Microsoft Excel dan SPSS. Yogyakarta: Andi Offset. 
Setiawati, L. dan A. Na.im. 2000. Manajemen Laba. Journal Ekonomi dan Bisnis. Mei: 159-176.

Sulistyanto, Sri. 2008. Manajemen Laba Teori dan Model Empiris. Grasindo: Jakarta.

Utami, W. 2006. Pengaruh Manajemen Laba terhadap Biaya Modal Ekuitas (Studi pada Perusahaan Publik Sektor Manufaktur). Jurnal Riset Akuntansi Indonesia 9 (2): 178-199.

Wasilah. 2005. Hubungan Asimetri Informasi dan Praktik Perataan Laba di Indonesia. Jurnal Akuntansi dan Keuangan. Vol. 2, No. 1. Hal. 123.

www.google.com

www.idx.co.id 